\title{
Studies on Effect of Different Levels of Sulphur Application with Combined Use of Organic Manures on Nutrients Uptake, Nutrients-Relationships and Protein Content in Indian Mustard
}

\author{
Anand Prasad Rakesh ${ }^{1}$ and Vandana Kumari ${ }^{2 *}$ \\ ${ }^{1}$ K.V.K. Jale, Darbhanga, Bihar, India \\ ${ }^{2}$ Department of Soil Science, Dr. Rajendra Prasad Central Agricultural University, \\ Pusa, Samastipur, Bihar, India, 848125 \\ *Corresponding author
}

\section{A B S T R A C T}

\section{Keywords \\ Organic manures, Mustard, Direct effect, Biogas slurry, Sulphur, nutrient uptake}

Article Info

Accepted:

22 March 2020

Available Online:

10 April 2020
An experiment was conducted to evaluate the direct effect of different level of sulphur (S) alone or in combination with organic manures on mustard in calcareous soil of north India. Sulphur application significantly increased the $S$ concentration and its uptake by mustard (seed+stover). The optimum level of $\mathrm{S}$ was found to be $60 \mathrm{~kg} \mathrm{~S}^{-1}$ in conjoint with $5 \mathrm{t}$ Bio Gas Slurry (BGS) ha $^{-1}$ for mustard crop with respect to concentration and nutrient uptake. The maximum total N, P and K uptake of 69.5, 21.2 and $85.7 \mathrm{~kg} \mathrm{ha}^{-1}$ respectively was recorded at $60 \mathrm{~kg} \mathrm{~S}^{-1}$ showing the synergistic behaviour at lower level of S-application with $\mathrm{N}, \mathrm{P}$ and $\mathrm{K}$ content in seed and stover and antagonistic at higher level of S-application. The beneficial effect of organic manure was also apparent in increasing total $\mathrm{N}, \mathrm{P}$ and $\mathrm{K}$ uptake from 51.9 to 56.6, 15.9 to 19.6 and 66.8 to $73.4 \mathrm{~kg} \mathrm{ha}^{-1}$, respectively. Biogas slurry (BGS) proved better as compared to FYM in increasing total $\mathrm{N}, \mathrm{P}$ and $\mathrm{K}$ uptake by mustard. The optimum $\mathrm{N}$ : S ratios were worked out to be 3.57 and 1.72 in mustard seed and stover, respectively. The optimum P: S ratios for mustard seed and stover were 1.53 and 0.37 , respectively. Sulphur application enhanced the protein content in mustard seed from 13.5 per cent to 18.2 per cent.

\section{Introduction}

The continuous mining of nutrients from soils coupled with inadequate and imbalanced fertilizer use has resulted in emergence of multi nutrient deficiencies. Sulphur (S) helps in the synthesis of cysteine, methionine, chlorophyll, vitamins (B, biotin and thiamine), metabolism of carbohydrates, especially by its effect on the protolytic enzymes (Najar et al., 2011). It is also necessary for chlorophyll formation and helps in biosynthesis of oil and metabolism of carbohydrates, proteins and fats and thus now-a day sulphur is being considered as the fourth major nutrient element after NPK (Das 
et al., 2016). Nitrogen and sulphur both have important role in protein and oil production. Hence, the interaction between $\mathrm{N}$ and $\mathrm{S}$ is generally positive or sometimes additive (no interaction). In a field trials having $5.6 \mathrm{ppm}$ available-S, $25 \%$ of total increase in oil yield of mustard due to $\mathrm{N}+\mathrm{S}$ application could be attributed to their synergistic effect (Sachdev and Dev, 1990; Pasricha et al., 1987). The combined application of $\mathrm{N}$ and $\mathrm{S}$ on Chinese cabbage and Fodder brassica gave 10\% extra response than the sum of their individual effect in Chinese cabbage. Whereas, in case of fodder brassica, the response to $\mathrm{N}$ and $\mathrm{S}$ was about $7 \%$ less than the sum of their individual responses (Hazra, 1988). The effect of sulphur application on percent Nitrogen content of grain and stover of rapeseed had a marked effect on increasing $\mathrm{N}$ content of grain and stover. $\mathrm{N}$ application @ 60 and 90 $\mathrm{kg} \mathrm{ha}{ }^{-1}$ and $\mathrm{S} @ 30$ and $45 \mathrm{~kg} \mathrm{ha}{ }^{-1}$ significantly increased $\mathrm{N}$ content over all other $\mathrm{N}$ and $\mathrm{S}$ levels of sulphur and nitrogen fertilization on $\mathrm{N}$ uptake by rapeseed. However, the highest level of $\mathrm{S}$ showed a decreasing trend of $\mathrm{N}$ content in rapeseed grain (Das and Das, 1994). Significant interaction effect of $\mathrm{N}$ and $\mathrm{S}$ was also observed in both seed and stover of gobhi sarson (Brassica napus L., ISN-706) by Biswas et al., (1995). The yield of seed and stovercould be attributed to the synergistic effect of $\mathrm{S}$ on $\mathrm{N}$ for the formation of more metabolites. Also, the significant increase of mean uptake of $\mathrm{N}$ was observed with increasing level of $\mathrm{S}$. The maximum total uptake of $\mathrm{N}$ was obtained with combined application of $120 \mathrm{~kg} \mathrm{~N}$ and $50 \mathrm{~kg} \mathrm{~S} \mathrm{ha}^{-1}$ treatment. This may also be due to synergistic mechanism of $\mathrm{N}$ and $\mathrm{S}$.

The nature of phosphorus and sulphur interaction may be positive or negative but recent research has shown that the nature of phosphorus and sulphur interaction depends on their rate of application. The synergistic effect of phosphorus and sulphur is reported at low-medium levels of $\mathrm{P}$ and antagonistic only at higher levels, usually at $60 \mathrm{~kg} \mathrm{P}_{2} \mathrm{O}_{5}$ $\mathrm{ha}^{-1}$ or more for field crops (Pasricha et al., 1987; Aulakh et al., 1990). Similarly, Ali (1991) on a field experiment with pigeonpea at Kanke, Bihar showed that the $\mathrm{P} \times \mathrm{S}$ interaction was rate dependent. The $\mathrm{P} \times \mathrm{S}$ interaction was absent at 20-40 $\mathrm{kg} \mathrm{P}_{2} \mathrm{O}_{5}$ with $20 \mathrm{~kg} \mathrm{~S} \mathrm{ha}{ }^{-1}$, strongly synergistic at $40-60 \mathrm{~kg}$ $\mathrm{P}_{2} \mathrm{O}_{5}$ with $20-40 \mathrm{~kg} \mathrm{~S}$ and antagonistic at 60 $\mathrm{kg} \mathrm{P}_{2} \mathrm{O}_{5}+40 \mathrm{~kg} \mathrm{~S} \mathrm{ha}^{-1}$.

There was consistent increase in $\mathrm{P}$ uptake with increasing levels of sulphur by grain. Application of $\mathrm{S}$, on the other hand, did not affect phosphorus content of both grain and stover significantly (Das and Das, 1994). Total P uptake (seed + stover) increased significantly with increasing level of $S$ proving positive interaction effects of these nutrients (Chaubey and Dwivedi, 1995). This increase in $\mathrm{P}$ concentration due to $\mathrm{S}$ incorporation might possibly be owing to the mobilization of soil $\mathrm{P}$ into available form for plant use.

Rauth and Ali (1985) reported a positive interaction between $\mathrm{P}$ and $\mathrm{S}$ in rapeseed and mustard. Sulphur increased seed yield by $41 \%, \mathrm{P}$ by $49 \%$ and the remaining $10 \%$ was reported to their synergistic effect.

Brassica oil crops responded positively to the combined application of $S$ and $K$ resulting in maximum grain yield, concentration, uptake and recovery of each other (Pasricha et al., 1987). The uptake of potassium and other major nutrients by blackgram due to $\mathrm{S}$ applied through different sources was significantly higher than control (Dwivedi et al., 1996). It shows the positive interaction of sulphur with potassium, Kachhave et al., (1997) advocated that the uptake of potassium and other major nutrients $(\mathrm{N}, \mathrm{P}$ and $\mathrm{S}$ ) increased significantly with increasing dose of sulphur. Keeping this 
in view of these aspects with respect to soils of Bihar in general and calcareous soils of north Bihar in particular prompted to undertake the present investigation.

\section{Materials and Methods}

A field experiment was conducted on calcareous soil under mustard-rice cropping system in the nursery Jhilley of Pusa farm, Bihar which was found deficient in available sulphur. Before sowing a composite sample was taken and was analysed for their general properties following standard methods. Soil $\mathrm{pH}$ was determined in a soil suspension in water with soil and water ratio of $1: 2$ by using glass electrode $\mathrm{pH}$ meter (Jackson,1978) and electrical conductivity was determined with the help of conductivity bridge (Jackson, 1978). Organic carbon was estimated by the wet digestion method as given by Walkley and Black (1934). Determination of micronutrients like $\mathrm{Zn}, \mathrm{Fe}, \mathrm{Cu}$ and $\mathrm{Mn}$ was done with the help of atomic absorption spectrophotometer in DTPA extract as suggested by Lindsay and Norvell (1978). Available sulphur was determined by turbidimetric method as given by Chesnine and Yien (1951). The experimental site was sandy loam in texture, slightly alkaline in reaction, low in organic carbon, available $\mathrm{N}$, $\mathrm{P}, \mathrm{K}$ and $\mathrm{S}$ (Table 1). The treatment consisted of seven level of sulphur $(0,20,40,60,80$, 100 and $120 \mathrm{~kg} \mathrm{~S} \mathrm{ha}^{-1}$ ) alone or along with organic manures and were replicated thrice in randomised block design. Source of $\mathrm{S}$ Phosphogypsum (1 \% $\mathrm{P}_{2} \mathrm{O}_{5}$ and $14 \%$ S), Source of organic manure-FYM/ Biogas slurry $\left(5.0 \mathrm{t} \mathrm{ha}^{-1}\right)$. Mustard (var. Varuna) was grown as test crop successively to see the direct effect of sulphur alone or along with organic manure.

The required quantity of two source of organic manure i.e. FYM and Biogas slurry (BGS) were amended with different level of sulphur and incubated for one month before application in mustard (Table 2 and 3). The recommended dose of $80 \mathrm{~kg} \mathrm{~N}, 40 \mathrm{~kg} \mathrm{P}_{2} \mathrm{O}_{5}$ and $40 \mathrm{~kg} \mathrm{~K}_{2} \mathrm{O}$ ha $^{-1}$ in mustard as urea, DAP and Murate of Potash, respectively were added. Since the plot was deficient in available $\mathrm{Zn}$, a basal application of $10 \mathrm{~kg} \mathrm{Zn}$ as Zinc oxide was done uniformly to all plots. Crop was grown till maturity to records yield. Grain and stover samples of crop were taken from each plot for their chemical analysis. Plant samples were collected and dried in the oven at $65 \pm 1{ }^{0} \mathrm{C}$ and ground in Willey mill fitted with stainless steel blades. Plant samples were digested as per procedure described by Piper (1966) in binary acid mixture of nitric and perchloric acid (10: 3)for extraction of total sulphur content as per the method of Tabatabai (1982). It was heated on hot plate till complete digestion. Residue in the flask was dissolved in distilled water and finally volume was made in $50 \mathrm{ml}$ volumetric flask. The dissolved matter was filter with filter paper No. 1 and analysis of $\mathrm{P}, \mathrm{K}$ and $\mathrm{S}$ was done as per the procedures described by Jackson (1978). Total $\mathrm{N}$ was analysed by Kjeldahl digestion distillation method as described by Piper (1966).Sulphur in the extract was determined by turbidimetric method given by Chesnine and Yien (1951). The average nitrogen $(\mathrm{N})$ content of proteins was found to be 16 percent which led to use of calculation for protein content given as:protein content $=\mathrm{Nx} 6.25$ (Food energymethods of analysis and conversion factors FAO food and nutrition paper 77, 2002).

\section{Results and Discussion}

\section{Direct effect of sulphur on nitrogen concentration and uptake on mustard crop}

The nitrogen concentration in mustard seed and stover varied from 2.120 to 3.050 and 0.550 to 0.880 per cent, respectively which was found to be significantly increased with 
increasing S-levels upto $60 \mathrm{~kg} \mathrm{~S} \mathrm{ha}^{-1}$ (Table 4). A favourable effect of $S$ on $N$ content in mustard was also reported by Das and Das (1994). Surprisingly, there was significant decrease in $\mathrm{N}$ concentration in mustard seed with the application of sulphur along with FYM and BGS. Although, there was significant improvement in the $\mathrm{N}$ concentration of mustard stover when sulphur was applied with organic manure. The decrease in seed $\mathrm{N}$ content might be due to dilution effect as the seed yield was significantly increased due to organic manure application. Secondly, the N applied through organic manure was compensated in treatments receiving no organic manure. The interaction effect of organic manure and $\mathrm{S}$ levels in case of $\mathrm{N}$ concentration in mustard seed was significant. The data revealed that at lower $\mathrm{S}$ level, the $\mathrm{N}$ concentration was increased whereas at higher $S$ level it was decreased irrespective of $S$ application mode whether applied alone or along with organic manure.

Significant increase in mean N-uptake by seed, stover and total uptake was observed with increasing level of sulphur upto $60 \mathrm{~kg} \mathrm{~S}$ $\mathrm{ha}^{-1}$ where the values were $33.7,35.9$ and $69.5 \mathrm{~kg} \mathrm{ha}^{-1}$, respectively (Table 5). Beyond this level there was decline in uptake and lowest was observed at $120 \mathrm{~kg} \mathrm{~S} \mathrm{ha}{ }^{-1}$. This may be due to synergistic uptake mechanism of $\mathrm{N}$ and $\mathrm{S}$ upto $60 \mathrm{~kg} \mathrm{~S} \mathrm{ha}{ }^{-1}$. This increase can again be attributed to increase in dry matter yield and higher nutrient demand for plant growth. Similar observations were recorded by Das and Das (1994) and Biswas et al., (1995). Biogas slurry proved to be superior source of organic matter for increasing the $\mathrm{N}$ uptake by both seed and stover. This may be attributed to the readily available nature of nutrients in BGS compared to FYM did not exhibit any increase in the mean $\mathrm{N}$ uptake by mustard seed. Although, it produced significant effect in case of $\mathrm{N}$ uptake by mustard stover.
Direct effect of sulphur on phosphorus concentration and uptake on mustard crop

Data presented in Table 6 showed the variation in $\mathrm{P}$ content in mustard seed and stover from 0.993 to 1.247 and 0.090 to 0.203 per cent, respectively due to various $S$ treatments. The mean P-concentration in seed and stover was increased progressively from 1.048 to 1.194 and 0.116 to 0.173 per cent, respectively due to increasing levels of $S$ upto $60 \mathrm{~kg} \mathrm{~S} \mathrm{ha}{ }^{-1}$. Similar increase in P content by $\mathrm{S}$-application in winter maize in calcareous soil of Bihar was also reported by Sinha et al., (1995). Organic manure application significantly increased the P-concentration in seed and stover except with FYM in seed which might be due to immobilization of available $\mathrm{P}$ by microbes during the decomposition of FYM. The interaction of organic manure and S-levels was significant and positive in influencing the P-content in mustard seed and stover, although FYM has negative influence in increasing the P-content in seed. This shows the more degradable nature of BGS in soil owing to the mobilization of soil $\mathrm{P}$ into available form for plant uptake. The interaction effect suggested the superiority of $60 \mathrm{~kg} \mathrm{~S}^{-1}$ level along with BGS in mobilizing soil-P.

The P uptake by mustard seed, stover and total uptake as influenced by organic manures and different sulphur levels alone or in combination was found to vary from 8.3 to $15.7,3.0$ to 8.3 and 11.3 to $24.0 \mathrm{~kg} \mathrm{ha}^{-1}$, respectively (Table 7 ). Sulphur application upto $60 \mathrm{~kg} \mathrm{ha}^{-1}$ level progressively increased the $\mathrm{P}$ uptake by seed and stover from 9.5 to 13.8 and 4.2 to $7.7 \mathrm{~kg} \mathrm{ha}^{-1}$, respectively. Beyond this level the $\mathrm{P}$ uptake was significantly decreased progressively suggesting thereby synergistic effect of $\mathrm{S}$ on $\mathrm{P}$ at lower level of $S$ application but antagonistic effect at higher level of $S$ application. This result confirmed the findings of many workers like Patel and Patel (1994), Randhawa (1995), Sinha et al., (1995) and 
Sarkunan et al., (1998) who had reported such results for crops like lucern, wheat, winter maize and rice, respectively. The effect of organic manure on $\mathrm{P}$ uptake followed the trend of concentration in mustard. The interaction effect between organic manures and S-levels was also significant which indicated that $60 \mathrm{~kg} \mathrm{~S}^{-1}$ in combination with $50 \mathrm{q} \mathrm{ha}^{-1}$ BGS was the best treatment combination with respect to $\mathrm{P}$ uptake by mustard.

\section{Direct effect of sulphur on potassium concentration and uptake on mustard crop}

Potassium concentration in mustard seed and stover varied from 0.547 to 0.790 per cent and 1.413 to 1.920 per cent, respectively with the application of sulphur alone or along with organic manure (Table 8). The mean $\mathrm{K}$ concentration in seed and stover increased progressively from 0.629 to 0.790 and 1.419 to 1.796 per cent, respectively with increasing levels of S upto $60 \mathrm{~kg} \mathrm{ha}^{-1}$ Beyond this level, there was decline in $\mathrm{K}$-content and lowest being observed with $120 \mathrm{~kg} \mathrm{~S} \mathrm{ha}{ }^{-1}$ The synergistic effect of $\mathrm{S}$ on $\mathrm{K}$ concentration at lower level of $\mathrm{S}$ and antagonistic effect at higher levels of $\mathrm{S}$ was also observed by Jaggi et al., (1995) in linseed crop. There was significant positive effect of FYM and BGS in increasing the K-content in mustard seed. The FYM was found to significantly decrease the K-content in mustard stover but BGS did not change the K-concentration. The interaction effect of $\mathrm{S}$ levels and organic manures was significant only in case of stover which again indicated the superiority of BGS over FYM with respect to K-nutrition.

Direct effect of sulphur application alone or along with organic manure on Potassium uptake by mustard has been presented in Table 9. Potassium uptake by mustard seed, stover and total uptake varied from 4.6 to $10.5,47.6$ to 84.8 and 52.1 to $95.2 \mathrm{~kg} \mathrm{ha}^{-1}$, respectively. The mean K-uptake in seed and stover increased progressively from 5.7 to 9.2 and 51.5 to $76.6 \mathrm{~kg} \mathrm{ha}^{-1}$, respectively with mean total K-uptake from 57.2 to $85.7 \mathrm{~kg} \mathrm{ha}^{-1}$ with increasing $\mathrm{S}$ levels upto $60 \mathrm{~kg} \mathrm{ha}^{-1}$ beyond which the K-uptake was significantly reduced. The synergistic effect of sulphur on K-uptake at lower levels of sulphur and antagonistic effect at its higher level confirm the findings of Jaggi et al., (1995). The significant positive effect of BGS in increasing K-uptake by seed and stover is apparent, however, FYM did not produce its significant effect in increasing the K-uptake by stover and total Kuptake by mustard. The first order interaction was also found to be significant in affecting K-uptake by mustard. This suggested that $\mathrm{S}$ application either alone or in combination with organic manures especially BGS was able to dissolve native $\mathrm{K}$ to make it available for plants.

\section{Direct effect of sulphur application alone or along with organic manure on $\mathrm{N}$ : $\mathrm{S}$ ratio}

The data on $\mathrm{N}$ : $\mathrm{S}$ ratio in mustard seed and stover as influenced by different levels of $\mathrm{S}$ alone or along with organic manure have been portrayed in Table 10 which varied from 2.51 to 3.80 and 1.10 to 1.72 , respectively. The mean $\mathrm{N}$ : $\mathrm{S}$ ratio in mustard seed was increased from 2.57 to 3.54 with increasing $\mathrm{S}$ levels upto $60 \mathrm{~kg} \mathrm{ha}^{-1}$ beyond which it was decreased. However, in case of stover though the effect of $S$ levels was irregular initially but at higher levels this ratio decreased. The reduction of $\mathrm{N}$ : $\mathrm{S}$ ratio due to $\mathrm{S}$ application has also been reported by Sharma et al., (1991); Das and Das (1994); Patel and Patel (1994). The effect of organic manures was non-significant in case of $\mathrm{N}: \mathrm{S}$ ratio in stover but $\mathrm{N}: \mathrm{S}$ ratio in mustard seed was reduced significantly and the higher reduction was noted in case of FYM This suggested that organic manure not only stabilized the added $S$ but also solubilized the native $S$ and the extent of dissolution was more for $\mathrm{S}$ as compared to $\mathrm{N}$. The interaction effect was 
also significant in changing $\mathrm{N}$ : $\mathrm{S}$ ratio in mustard. Since previous results suggested 60 $\mathrm{kg} \mathrm{S} \mathrm{ha}{ }^{-1}$ along with BGS as the Optimum treatment combination for mustard, hence, $\mathrm{N}$ : $S$ ratio at this treatment combination i.e. 3.57 for mustard seed and 1.72 for mustard stover may be treated as optimum $\mathrm{N}$ : $\mathrm{S}$ ratio for mustard production.

\section{Direct effect of sulphur on $\mathrm{P}: \mathrm{S}$ ratio}

Both N: S and P: S ratio are good indices for differentiating the normal plant from sulphur deficient one. P: $S$ ratio in mustard seed and stover as affected by different S-levels alone or along with organic manures have been presented in Table 11. The P: $\mathrm{S}$ ratio in mustard seed and stover varied from 1.06 to 1.56 and 0.15 to 0.39 , respectively. The highest mean P: S ratio was recorded at $60 \mathrm{~kg}$ $\mathrm{S} \mathrm{ha}^{-1}$ level which significantly decreased with further increase in $S$ levels. The effect of organic manure and interaction effect on $\mathrm{P}: \mathrm{S}$ ratio was very much similar to $\mathrm{N}$ : $\mathrm{S}$ ratio.

Table.1 General properties of initial surface soil of experimental plot

\begin{tabular}{|l|l|l|}
\hline S.No. & Soil Properties & Content \\
\hline 1. & Sand $(\%)$ & 76.0 \\
\hline & Silt $(\%)$ & 12.0 \\
\hline & Clay $(\%)$ & 12.0 \\
\hline & Textural class & Sandy loam \\
\hline 2. & $\mathrm{pH}(1: 2)$ & 8.4 \\
\hline 3. & EC $\left(\mathrm{dSm}^{-1}\right)$ & 0.35 \\
\hline 4. & Organic carbon $\left(\mathrm{g} \mathrm{kg}^{-1}\right)$ & 4.10 \\
\hline $\mathbf{5 .}$ & Free $\mathrm{CaCO}_{3}\left(\mathrm{~g} \mathrm{~kg}^{-1}\right)$ & 334 \\
\hline 6. & CEC $\left[{\left.\mathrm{Cmol}\left(\mathrm{P}^{+}\right) \mathrm{kg}^{-1}\right]}^{-1}\right)$ & 8.80 \\
\hline 7. & Available N $\left(\mathrm{kg} \mathrm{h}^{-1}\right)$ & 240 \\
\hline & $\mathrm{P}_{2} \mathrm{O}_{5}\left(\mathrm{~kg} \mathrm{ha}^{-1}\right)$ & 14 \\
\hline $\mathrm{K}_{2} \mathrm{O}\left(\mathrm{kg} \mathrm{ha}^{-1}\right)$ & 78 \\
\hline 8. & Available $\mathrm{Zn}\left(\mathrm{mg} \mathrm{kg}^{-1}\right)$ & 0.57 \\
\hline 9. & Available $\mathrm{Fe}\left(\mathrm{mg} \mathrm{kg}^{-1}\right)$ & 20.55 \\
\hline 10. & Available Cu $\left(\mathrm{mg} \mathrm{kg}^{-1}\right)$ & 3.62 \\
\hline 11. & Available $\mathrm{Mn}\left(\mathrm{mg} \mathrm{kg}^{-1}\right)$ & 9.92 \\
\hline 12. & Total S & 349.8 \\
\hline 13. & Available S & 8.26 \\
\hline & & \\
\hline
\end{tabular}


Table.2 Chemical composition of untreated organic manures used in the experiment before incubation

\begin{tabular}{|c|c|c|}
\hline Parameters & FYM & BGS \\
\hline Organic C $\left(\mathrm{g} \mathrm{kg}^{-1}\right)$ & 353 & 452 \\
\hline Total N (\%) & 0.84 & 1.29 \\
\hline $\mathbf{P}(\%)$ & 0.75 & 0.93 \\
\hline $\mathbf{K}(\%)$ & 0.69 & 1.12 \\
\hline S $(\%)$ & 0.63 & 0.82 \\
\hline $\mathrm{Zn}\left(\mathrm{mg} \mathrm{kg}^{-1}\right)$ & 79 & 102 \\
\hline Fe $\left(\mathrm{mg} \mathrm{kg}^{-1}\right)$ & 2421 & 2508 \\
\hline $\mathrm{Cu}\left(\mathrm{mg} \mathrm{kg}^{-1}\right)$ & 39 & 50 \\
\hline $\operatorname{Mn}\left(\mathrm{mg} \mathrm{kg}^{-1}\right)$ & 172 & 228 \\
\hline
\end{tabular}

Table. $3 \mathrm{CaCl}_{2}$ extractable sulphur in incubated organic matter at the time of application

\begin{tabular}{|l|c|c|c|c|}
\hline \multirow{2}{*}{ S levels } & \multicolumn{2}{|c|}{ FYM } & \multicolumn{2}{c|}{ BGS } \\
\cline { 1 - 5 } & $\mathbf{S}_{\text {conc }}(\boldsymbol{\%})$ & $\begin{array}{c}\text { Amount of S } \\
\text { added }\left(\mathbf{k g ~ h a} \mathbf{~}^{-1}\right)\end{array}$ & $\mathbf{S}_{\text {conc }}(\boldsymbol{\%})$ & $\begin{array}{c}\text { Amount of S } \\
\text { added (kg ha-1 }\end{array}$ \\
\hline $\mathbf{S}_{\mathbf{0}}$ & 0.138 & 7 & 0.40 & 20 \\
\hline $\mathbf{S}_{\mathbf{2 0}}$ & 0.729 & 37 & 1.092 & 55 \\
\hline $\mathbf{S}_{\mathbf{4 0}}$ & 1.362 & 68 & 2.045 & 102 \\
\hline $\mathbf{S}_{\mathbf{6 0}}$ & 2.174 & 109 & 2.554 & 128 \\
\hline $\mathbf{S}_{\mathbf{8 0}}$ & 2.679 & 134 & 3.250 & 163 \\
\hline $\mathbf{S}_{\mathbf{1 0 0}}$ & 3.291 & 165 & 4.008 & 200 \\
\hline $\mathbf{S}_{\mathbf{1 2 0}}$ & 3.866 & 193 & 4.601 & 230 \\
\hline
\end{tabular}

N.B. Dose of organic manure application $=50 \mathrm{q} \mathrm{ha}^{-1}$

Table.4 Direct effect of sulphur application alone or along with organic manure on nitrogen concentration $(\%)$ in mustard

\begin{tabular}{|c|c|c|c|c|c|c|c|c|}
\hline \multirow{3}{*}{$\begin{array}{l}\text { Sulphur } \\
\text { levels } \\
\left(\mathrm{kg} \mathrm{ha}^{-1}\right)\end{array}$} & \multicolumn{4}{|c|}{$\mathbf{N}$ concentration in seed } & \multicolumn{4}{|c|}{$\mathbf{N}$ concentration in stover } \\
\hline & \multicolumn{4}{|c|}{ Organic manures } & \multicolumn{4}{|c|}{ Organic manures } \\
\hline & Control & FYM & BGS & Mean & Control & FYM & BGS & Mean \\
\hline $\mathbf{0}$ & 2.193 & 2.120 & 2.177 & 2.163 & 0.550 & 0.60 & 0.653 & 0.601 \\
\hline 20 & 2.297 & 2.230 & 2.270 & 2.266 & 0.650 & 0.677 & 0.707 & 0.678 \\
\hline 40 & 2.540 & 2.467 & 2.450 & 2.486 & 0.713 & 0.750 & 0.743 & 0.735 \\
\hline 60 & 3.050 & 2.793 & 2.900 & 2.914 & 0.787 & 0.860 & 0.877 & 0.841 \\
\hline 80 & 2.907 & 2.540 & 2.423 & 2.623 & 0.850 & 0.880 & 0.810 & 0.847 \\
\hline 100 & 2.330 & 2.360 & 2.300 & 2.330 & 0.800 & 0.800 & 0.750 & 0.783 \\
\hline 120 & 2.177 & 2.270 & 2.290 & 2.246 & 0.733 & 0.723 & 0.736 & 0.731 \\
\hline Mean & 2.499 & 2.397 & 2.401 & & 0.726 & 0.756 & 0.754 & \\
\hline \multicolumn{2}{|l|}{ Sources } & \multicolumn{2}{|c|}{ S.Em \pm} & \multicolumn{2}{|c|}{$\mathrm{CD}(\mathrm{P}=0.05)$} & S.Em \pm & \multicolumn{2}{|c|}{$\mathrm{CD}(\mathrm{P}=\mathrm{O} .05)$} \\
\hline \multicolumn{2}{|c|}{ Organic manures } & \multicolumn{2}{|c|}{0.014} & \multicolumn{2}{|c|}{0.041} & 0.01 & \multicolumn{2}{|c|}{0.027} \\
\hline \multicolumn{2}{|l|}{ S levels } & \multicolumn{2}{|c|}{0.022} & \multicolumn{2}{|c|}{0.063} & 0.015 & \multicolumn{2}{|c|}{0.042} \\
\hline \multicolumn{2}{|c|}{ Interactions } & \multicolumn{2}{|c|}{0.038} & \multicolumn{2}{|c|}{0.109} & 0.025 & & \\
\hline
\end{tabular}


Table.5 Direct effect of sulphur application alone or along with organic manure on nitrogen uptake $\left(\mathrm{kg} \mathrm{ha}^{-1}\right) \mathrm{by} \mathrm{mustard}^{-1}$

\begin{tabular}{|c|c|c|c|c|c|c|c|c|c|c|c|c|}
\hline \multirow{3}{*}{$\begin{array}{c}\text { Sulphur } \\
\text { levels } \\
\left(\mathrm{kg} \mathrm{ha}^{-1}\right)\end{array}$} & \multicolumn{4}{|c|}{ N uptake by mustard seed } & \multicolumn{4}{|c|}{ N uptake by mustard stover } & \multicolumn{4}{|c|}{ Total nitrogen uptake by mustard } \\
\hline & \multicolumn{4}{|c|}{ Organic manures } & \multicolumn{4}{|c|}{ Organic manures } & \multicolumn{4}{|c|}{ Organic manures } \\
\hline & Control & FYM & BGS & Mean & Control & FYM & BGS & Mean & Control & FYM & BGS & Mean \\
\hline $\mathbf{0}$ & 18.3 & 19.1 & 21.0 & 19.5 & 18.5 & 21.9 & 25.3 & 21.9 & 36.8 & 41.0 & 46.3 & 41.4 \\
\hline 20 & 21.8 & 23.0 & 24.2 & 23.0 & 22.8 & 25.8 & 28.2 & 25.6 & 44.7 & 48.8 & 52.3 & 48.6 \\
\hline 40 & 24.6 & 26.3 & 26.6 & 25.8 & 27.8 & 29.6 & 30.8 & 29.4 & 52.4 & 56.0 & 57.4 & 55.2 \\
\hline 60 & 33.1 & 31.2 & 36.7 & 33.7 & 32.7 & 36.3 & 38.7 & 35.9 & 65.7 & 67.4 & 75.5 & 69.5 \\
\hline 80 & 29.5 & 27.5 & 26.7 & 27.9 & 32.6 & 33.6 & 33.2 & 33.1 & 62.1 & 61.1 & 59.8 & 61.0 \\
\hline 100 & 23.3 & 23.2 & 23.8 & 23.4 & 30.3 & 30.2 & 30 & 30.2 & 53.5 & 53.4 & 53.8 & 53.6 \\
\hline 120 & 21.5 & 22.0 & 22.5 & 22.0 & 26.9 & 26.2 & 28.4 & 27.2 & 48.5 & 48.2 & 50.9 & 49.2 \\
\hline Mean & 24.6 & 24.6 & 25.9 & & 27.4 & 29.1 & 30.7 & & 51.9 & 53.7 & 56.6 & \\
\hline \multicolumn{2}{|c|}{ Sources } & \multicolumn{3}{|c|}{ S.Em \pm} & \multicolumn{2}{|c|}{$\mathrm{CD}(\mathrm{P}=0.05)$} & \multicolumn{2}{|c|}{ S.Em \pm} & $(\mathrm{P}=0.05)$ & \multicolumn{2}{|c|}{ S.Em \pm} & $\begin{array}{c}C D \\
P=0.05)\end{array}$ \\
\hline \multicolumn{2}{|c|}{ Organic manures } & \multicolumn{3}{|c|}{0.4} & \multicolumn{2}{|l|}{1.1} & \multicolumn{2}{|l|}{0.4} & 1.2 & \multicolumn{2}{|c|}{0.5} & 1.5 \\
\hline \multicolumn{2}{|c|}{ S levels } & \multicolumn{3}{|c|}{0.6} & \multicolumn{2}{|l|}{1.7} & \multicolumn{2}{|l|}{0.6} & 1.8 & \multicolumn{2}{|c|}{0.8} & 2.3 \\
\hline \multicolumn{2}{|c|}{ Interaction } & \multicolumn{3}{|c|}{1} & & & \multicolumn{2}{|l|}{1.1} & & \multicolumn{2}{|c|}{1.4} & 3.9 \\
\hline
\end{tabular}


Table.6 Direct effect of sulphur application alone or along with organic manure on phosphorus concentration $(\%)$ in mustard

\begin{tabular}{|c|c|c|c|c|c|c|c|c|}
\hline \multirow{3}{*}{$\begin{array}{l}\text { Sulphur } \\
\text { levels } \\
\left(\mathrm{kg} \mathrm{ha}^{-1}\right)\end{array}$} & \multicolumn{4}{|c|}{$P$ concentration in seed } & \multicolumn{4}{|c|}{$P$ concentration in stover } \\
\hline & \multicolumn{4}{|c|}{ Organic manures } & \multicolumn{4}{|c|}{ Organic manures } \\
\hline & Control & FYM & BGS & Mean & Control & FYM & BGS & Mean \\
\hline $\mathbf{0}$ & 0.993 & 1.017 & 1.133 & 1.048 & 0.090 & 0.107 & 0.150 & 0.116 \\
\hline 20 & 1.083 & 1.083 & 1.163 & 1.110 & 0.093 & 0.123 & 0.157 & 0.124 \\
\hline 40 & 1.153 & 1.123 & 1.173 & 1.150 & 0.120 & 0.133 & 0.170 & 0.141 \\
\hline 60 & 1.197 & 1.143 & 1.243 & 1.194 & 0.193 & 0.140 & 0.187 & 0.173 \\
\hline 80 & 1.250 & 1.077 & 1.247 & 1.191 & 0.143 & 0.153 & 0.203 & 0.167 \\
\hline 100 & 1.250 & 1.057 & 1.23 & 1.178 & 0.100 & 0.143 & 0.180 & 0.141 \\
\hline 120 & 1.147 & 0.960 & 1.136 & 1.081 & 0.097 & 0.117 & 0.130 & 0.114 \\
\hline Mean & 1.153 & 1.066 & 1.190 & & 0.120 & 0.131 & 0.168 & \\
\hline \multicolumn{2}{|l|}{ Sources } & \multicolumn{2}{|c|}{ S.Em \pm} & \multicolumn{2}{|c|}{$\mathrm{CD}(\mathrm{P}=\mathrm{O} .05)$} & S.Em \pm & \multicolumn{2}{|c|}{$\mathrm{CD}(\mathrm{P}=\mathrm{O} .05)$} \\
\hline \multicolumn{2}{|c|}{ Organic manures } & \multicolumn{2}{|c|}{0.011} & \multicolumn{2}{|l|}{0.03} & 0.002 & \multicolumn{2}{|c|}{0.006} \\
\hline \multicolumn{2}{|l|}{ S levels } & \multicolumn{2}{|c|}{0.016} & \multicolumn{2}{|l|}{0.046} & 0.003 & \multicolumn{2}{|c|}{0.009} \\
\hline \multicolumn{2}{|c|}{ Interactions } & \multicolumn{2}{|c|}{0.028} & \multicolumn{2}{|l|}{0.079} & 0.006 & \multicolumn{2}{|c|}{0.016} \\
\hline
\end{tabular}


Table.7 Direct effect of sulphur application alone or along with organic manure on phosphorus uptake $\left(\mathrm{kg} \mathrm{ha}^{-1}\right)$ by mustard

\begin{tabular}{|c|c|c|c|c|c|c|c|c|c|c|c|c|}
\hline \multirow{3}{*}{$\begin{array}{c}\text { Sulphur } \\
\text { levels } \\
\left(\mathrm{kg} \mathrm{ha}^{-1}\right)\end{array}$} & \multicolumn{4}{|c|}{ P uptake by mustard seed } & \multicolumn{4}{|c|}{ P uptake by mustard stover } & \multicolumn{4}{|c|}{ Total phosphorus uptake by mustard } \\
\hline & \multicolumn{4}{|c|}{ Organic manures } & \multicolumn{4}{|c|}{ Organic manures } & \multicolumn{4}{|c|}{ Organic manures } \\
\hline & Control & FYM & BGS & Mean & Control & FYM & BGS & Mean & Control & FYM & BGS & Mean \\
\hline $\mathbf{0}$ & 8.3 & 9.2 & 11.0 & 9.5 & 3 & 3.9 & 5.8 & 4.2 & 11.3 & 13 & 16.8 & 13.7 \\
\hline 20 & 10.3 & 11.2 & 12.4 & 11.3 & 3.3 & 4.7 & 6.2 & 4.7 & 13.6 & 15.9 & 18.6 & 16.0 \\
\hline 40 & 11.1 & 12.0 & 12.7 & 11.9 & 4.7 & 5.3 & 7.1 & 5.7 & 15.8 & 17.2 & 19.8 & 17.6 \\
\hline 60 & 13.0 & 12.8 & 15.7 & 13.8 & 8.0 & 5.9 & 8.2 & 7.4 & 21.0 & 18.7 & 24.0 & 21.2 \\
\hline 80 & 12.7 & 11.7 & 13.7 & 12.7 & 5.5 & 5.9 & 8.3 & 6.6 & 18.2 & 17.6 & 22.0 & 19.3 \\
\hline 100 & 12.5 & 10.4 & 12.7 & 11.9 & 3.8 & 5.4 & 7.2 & 5.5 & 16.3 & 15.8 & 19.9 & 17.3 \\
\hline 120 & 11.3 & 9.3 & 11.2 & 10.6 & 3.6 & 4.2 & 5.0 & 4.3 & 14.8 & 13.5 & 16.2 & 14.8 \\
\hline Mean & 11.3 & 10.9 & 12.8 & & 4.6 & 5.0 & 6.8 & & 15.9 & 16 & 19.6 & \\
\hline \multicolumn{2}{|c|}{ Sources } & \multicolumn{3}{|c|}{ S.Em \pm} & \multicolumn{2}{|c|}{$\mathrm{CD}(\mathrm{P}=0.05)$} & S.Em \pm & \multicolumn{2}{|c|}{$\mathrm{CD}(\mathrm{P}=0.05)$} & \multicolumn{2}{|c|}{ S.Em \pm} & $\begin{array}{c}C D \\
(\mathrm{P}=0.05)\end{array}$ \\
\hline \multicolumn{2}{|c|}{ Organic manures } & \multicolumn{3}{|c|}{0.2} & \multicolumn{2}{|l|}{0.6} & \multicolumn{2}{|l|}{0.1} & 0.3 & \multicolumn{2}{|c|}{0.2} & 0.7 \\
\hline & vels & & 0.3 & & 0.9 & & 0.1 & & 0.4 & 0. & & 1.0 \\
\hline Int & ction & & 0.5 & & 1.5 & & 0.3 & & 0.7 & 0. & & 1.8 \\
\hline
\end{tabular}


Table.8 Direct effect of sulphur application alone or along with organic manure on potassium concentration (\%) in mustard

\begin{tabular}{|c|c|c|c|c|c|c|c|c|}
\hline \multirow{3}{*}{$\begin{array}{l}\text { Sulphur } \\
\text { levels } \\
\left(\mathrm{kg} \mathrm{ha}^{-1}\right)\end{array}$} & \multicolumn{4}{|c|}{$K$ concentration in seed } & \multicolumn{4}{|c|}{$K$ concentration in stover } \\
\hline & \multicolumn{4}{|c|}{ Organic manures } & \multicolumn{4}{|c|}{ Organic manures } \\
\hline & Control & FYM & BGS & Mean & Control & FYM & BGS & Mean \\
\hline $\mathbf{0}$ & 0.547 & 0.640 & 0.700 & 0.629 & 1.413 & 1.407 & 1.437 & 1.419 \\
\hline 20 & 0.59 & 0.660 & 0.783 & 0.678 & 1.553 & 1.497 & 1.507 & 1.519 \\
\hline 40 & 0.643 & 0.690 & 0.807 & 0.713 & 1.793 & 1.530 & 1.633 & 1.652 \\
\hline 60 & 0.757 & 0.783 & 0.830 & 0.790 & 1.853 & 1.613 & 1.920 & 1.796 \\
\hline 80 & 0.730 & 0.797 & 0.813 & 0.780 & 1.65 & 1.747 & 1.660 & 1.686 \\
\hline 100 & 0.677 & 0.740 & 0.780 & 0.732 & 1.547 & 1.597 & 1.603 & 1.582 \\
\hline 120 & 0.643 & 0.697 & 0.753 & 0.698 & 1.413 & 1.473 & 1.430 & 1.439 \\
\hline Mean & 0.655 & 0.715 & 0.781 & & 1.603 & 1.552 & 1.599 & \\
\hline \multicolumn{2}{|l|}{ Sources } & \multicolumn{2}{|c|}{ S.Em \pm} & \multicolumn{2}{|c|}{$\mathrm{CD}(\mathrm{P}=\mathrm{O} .05)$} & S.Em \pm & \multicolumn{2}{|c|}{$\mathrm{CD}(\mathrm{P}=\mathrm{O} .05)$} \\
\hline \multicolumn{2}{|c|}{ Organic manures } & \multicolumn{2}{|c|}{0.008} & \multicolumn{2}{|c|}{0.25} & 0.014 & \multicolumn{2}{|c|}{0.039} \\
\hline \multicolumn{2}{|l|}{ S levels } & \multicolumn{2}{|c|}{0.013} & \multicolumn{2}{|c|}{0.038} & 0.021 & \multicolumn{2}{|c|}{0.059} \\
\hline \multicolumn{2}{|c|}{ Interactions } & \multicolumn{2}{|c|}{0.023} & & & 0.036 & \multicolumn{2}{|c|}{0.103} \\
\hline
\end{tabular}


Table.9 Direct effect of sulphur application alone or along with organic manure on potassium uptake $\left(\mathrm{kg} \mathrm{ha}^{-1}\right)$ by mustard

\begin{tabular}{|c|c|c|c|c|c|c|c|c|c|c|c|c|}
\hline \multirow{3}{*}{$\begin{array}{c}\text { Sulphur } \\
\text { levels } \\
\left(\mathrm{kg} \mathrm{ha}^{-1}\right)\end{array}$} & \multicolumn{4}{|c|}{ K uptake by mustard seed } & \multicolumn{4}{|c|}{ K uptake by mustard stover } & \multicolumn{4}{|c|}{ Total potassium uptake by mustard } \\
\hline & \multicolumn{4}{|c|}{ Organic manures } & \multicolumn{4}{|c|}{ Organic manures } & \multicolumn{4}{|c|}{ Organic manures } \\
\hline & Control & FYM & BGS & Mean & Control & FYM & BGS & Mean & Control & FYM & BGS & Mean \\
\hline $\mathbf{0}$ & 4.6 & 5.8 & 6.8 & 5.7 & 47.6 & 51.3 & 55.6 & 51.5 & 52.1 & 57.1 & 62.3 & 57.2 \\
\hline 20 & 5.6 & 6.8 & 8.4 & 6.9 & 54.6 & 57.1 & 60 & 57.2 & 60.2 & 63.9 & 68.4 & 64.2 \\
\hline 40 & 6.2 & 7.4 & 8.7 & 7.4 & 69.9 & 60.5 & 67.8 & 66.1 & 76.1 & 67.8 & 76.5 & 73.5 \\
\hline 60 & 8.2 & 8.8 & 10.5 & 9.2 & 76.9 & 68.1 & 84.8 & 76.6 & 85.1 & 76.9 & 95.2 & 85.7 \\
\hline 80 & 7.4 & 8.7 & 9.0 & 8.4 & 63.3 & 66.7 & 68.1 & 66.0 & 70.7 & 75.3 & 77.1 & 74.4 \\
\hline 100 & 6.8 & 7.3 & 8.1 & 7.4 & 58.6 & 60.4 & 64.1 & 61.0 & 65.3 & 67.7 & 72.2 & 68.4 \\
\hline 120 & 6.4 & 6.7 & 7.4 & 6.8 & 51.8 & 53.6 & 55.0 & 53.5 & 58.2 & 60.4 & 62.4 & 60.3 \\
\hline Mean & 6.5 & 7.4 & 8.4 & & 60.4 & 59.7 & 65.0 & & 66.8 & 67.0 & 73.4 & \\
\hline \multicolumn{2}{|c|}{ Sources } & \multicolumn{2}{|c|}{ S.Em \pm} & \multicolumn{2}{|c|}{$\mathrm{CD}(\mathrm{P}=0.05)$} & \multicolumn{2}{|c|}{ S.Em \pm} & \multicolumn{2}{|c|}{$\mathrm{CD}(\mathrm{P}=0.05)$} & S.En & \multicolumn{2}{|c|}{$\mathrm{CD}(\mathrm{P}=0.05)$} \\
\hline \multicolumn{2}{|c|}{ Organic manures } & & 0.15 & \multicolumn{2}{|c|}{0.43} & \multicolumn{2}{|c|}{0.7} & \multicolumn{2}{|c|}{2.1} & 0.7 & \multicolumn{2}{|c|}{2.1} \\
\hline \multicolumn{2}{|c|}{ S levels } & & 0.23 & \multicolumn{2}{|c|}{0.65} & \multicolumn{2}{|c|}{1.1} & \multicolumn{2}{|c|}{3.2} & 1.1 & \multicolumn{2}{|c|}{3.1} \\
\hline \multicolumn{2}{|c|}{ Interaction } & & 0.39 & & & \multicolumn{2}{|c|}{1.9} & \multicolumn{2}{|c|}{5.5} & 1.5 & \multicolumn{2}{|c|}{5.5} \\
\hline
\end{tabular}


Table.10 Direct effect of sulphur application alone or along with organic manure on N:S ratio in mustard

\begin{tabular}{|c|c|c|c|c|c|c|c|c|}
\hline \multirow{3}{*}{$\begin{array}{l}\text { Sulphur } \\
\text { levels } \\
\left(\mathrm{kg} \mathrm{ha}^{-1}\right)\end{array}$} & \multicolumn{4}{|c|}{$\mathrm{N}: S$ ratio in mustard seed } & \multicolumn{4}{|c|}{$\mathrm{N}: \mathrm{S}$ ratio in mustard stover } \\
\hline & \multicolumn{4}{|c|}{ Organic manures } & \multicolumn{4}{|c|}{ Organic manures } \\
\hline & Control & FYM & BGS & Mean & Control & FYM & BGS & Mean \\
\hline $\mathbf{0}$ & 3.28 & 2.75 & 2.84 & 2.96 & 1.51 & 1.65 & 1.63 & 1.60 \\
\hline 20 & 3.14 & 2.66 & 2.91 & 2.90 & 1.68 & 1.42 & 1.48 & 1.53 \\
\hline 40 & 3.30 & 2.93 & 3.00 & 3.08 & 1.50 & 1.35 & 1.55 & 1.47 \\
\hline 60 & 3.80 & 3.25 & 3.57 & 3.54 & 1.52 & 1.50 & 1.72 & 1.58 \\
\hline 80 & 3.64 & 2.96 & 2.90 & 3.17 & 1.49 & 1.52 & 1.53 & 1.51 \\
\hline 100 & 2.86 & 2.71 & 2.70 & 2.76 & 1.35 & 1.37 & 1.23 & 1.32 \\
\hline 120 & 2.60 & 2.51 & 2.60 & 2.57 & 1.18 & 1.21 & 1.10 & 1.16 \\
\hline Mean & 3.23 & 2.82 & 2.93 & & 1.46 & 1.43 & 1.46 & \\
\hline \multicolumn{2}{|l|}{ Sources } & \multicolumn{2}{|c|}{ S.Em \pm} & \multicolumn{2}{|c|}{$\mathrm{CD}(\mathrm{P}=\mathrm{O} .05)$} & S.Em \pm & \multicolumn{2}{|c|}{$\mathrm{CD}(\mathrm{P}=\mathrm{O} .05)$} \\
\hline \multicolumn{2}{|c|}{ Organic manures } & \multicolumn{2}{|c|}{0.03} & \multicolumn{2}{|l|}{0.09} & 0.02 & \multicolumn{2}{|l|}{-} \\
\hline \multirow{2}{*}{\multicolumn{2}{|c|}{ S levels }} & \multicolumn{2}{|c|}{0.05} & \multicolumn{2}{|l|}{0.14} & 0.04 & \multicolumn{2}{|c|}{0.10} \\
\hline & & \multicolumn{2}{|c|}{0.08} & \multicolumn{2}{|l|}{0.24} & 0.06 & \multicolumn{2}{|c|}{0.18} \\
\hline
\end{tabular}

Table.11 Direct effect of sulphur application alone or along with organic manure on P:S ratio in mustard

\begin{tabular}{|c|c|c|c|c|c|c|c|c|}
\hline \multirow{3}{*}{$\begin{array}{l}\text { Sulphur } \\
\text { levels } \\
\left(\mathrm{kg} \mathrm{ha}^{-1}\right)\end{array}$} & \multicolumn{4}{|c|}{ P:S ratio in mustard seed } & \multicolumn{4}{|c|}{ P:S ratio in mustard stover } \\
\hline & \multicolumn{4}{|c|}{ Organic manures } & \multicolumn{4}{|c|}{ Organic manures } \\
\hline & Control & FYM & BGS & Mean & Control & FYM & BGS & Mean \\
\hline $\mathbf{0}$ & 1.41 & 1.32 & 1.48 & 1.40 & 0.25 & 0.29 & 0.37 & 0.30 \\
\hline 20 & 1.47 & 1.29 & 1.49 & 1.42 & 0.24 & 0.26 & 0.33 & 0.28 \\
\hline 40 & 1.50 & 1.33 & 1.44 & 1.42 & 0.23 & 0.24 & 0.35 & 0.27 \\
\hline 60 & 1.51 & 1.33 & 1.53 & 1.46 & 0.37 & 0.24 & 0.37 & 0.33 \\
\hline 80 & 1.56 & 1.25 & 1.49 & 1.43 & 0.25 & 0.26 & 0.39 & 0.30 \\
\hline 100 & 1.54 & 1.21 & 1.44 & 1.40 & 0.17 & 0.25 & 0.29 & 0.24 \\
\hline 120 & 1.37 & 1.06 & 1.29 & 1.24 & 0.15 & 0.18 & 0.20 & 0.18 \\
\hline Mean & 1.48 & 1.26 & 1.45 & & 0.24 & 0.25 & 0.33 & \\
\hline \multicolumn{2}{|l|}{ Sources } & \multicolumn{2}{|c|}{ S.Em \pm} & \multicolumn{2}{|c|}{$\mathrm{CD}(\mathrm{P}=0.05)$} & S.Em \pm & \multicolumn{2}{|c|}{$\mathrm{CD}(\mathrm{P}=\mathrm{O} .05)$} \\
\hline \multicolumn{2}{|c|}{ Organic manures } & \multicolumn{2}{|c|}{0.02} & \multicolumn{2}{|l|}{0.04} & 0.01 & \multicolumn{2}{|c|}{0.02} \\
\hline \multicolumn{2}{|c|}{$S$ levels } & \multicolumn{2}{|c|}{0.02} & & 0.01 & \multicolumn{2}{|c|}{0.02} \\
\hline \multicolumn{2}{|c|}{ Interactions } & \multicolumn{2}{|c|}{0.04} & \multicolumn{2}{|l|}{0.06} & 0.01 & \multicolumn{2}{|c|}{0.04} \\
\hline
\end{tabular}


Table.12 Direct effect of sulphur application alone or along with organic manure on protein content in mustard

\begin{tabular}{|c|c|c|c|c|}
\hline \multirow{2}{*}{$\begin{array}{c}\text { Sulphur } \\
\text { levels } \\
\left(\mathrm{kg} \mathrm{ha}^{-1}\right)\end{array}$} & \multicolumn{4}{|c|}{ Organic manures } \\
\hline & Control & FYM & BGS & Mean \\
\hline $\mathbf{0}$ & 13.52 & 13.25 & 13.61 & 13.46 \\
\hline 20 & 14.35 & 13.93 & 14.19 & 14.16 \\
\hline 40 & 15.87 & 15.42 & 15.31 & 15.53 \\
\hline 60 & 19.06 & 17.46 & 18.12 & 18.21 \\
\hline 80 & 18.17 & 15.87 & 15.14 & 16.39 \\
\hline 100 & 14.56 & 14.75 & 14.37 & 14.56 \\
\hline 120 & 13.6 & 14.19 & 14.31 & 14.03 \\
\hline Mean & 15.59 & 14.98 & 15.01 & \\
\hline Sources & \multicolumn{2}{|c|}{ S.Em \pm} & \multicolumn{2}{|c|}{$\mathrm{CD}(\mathrm{P}=\mathrm{O} .05)$} \\
\hline $\begin{array}{l}\text { Organic } \\
\text { manures }\end{array}$ & \multicolumn{2}{|c|}{0.09} & \multicolumn{2}{|c|}{0.21} \\
\hline S levels & \multicolumn{2}{|c|}{0.14} & \multicolumn{2}{|c|}{0.40} \\
\hline Interactions & \multicolumn{2}{|c|}{0.24} & \multicolumn{2}{|c|}{0.69} \\
\hline
\end{tabular}

\section{Direct effect of Sulphur on Protein content}

Effect of sulphur application alone or along with organic manure on protein content in mustard seed has been presented in Table 12 . Protein content mustard seed varied from 13.25 to 19.06 per cent. The mean protein content in increased progressively from 13.46 to 18.21 per cent with the application of $\mathrm{S}$ upto $60 \mathrm{~kg} \mathrm{ha}^{-1}$. It is conspicuous that increase in each $\mathrm{S}$ dose increased the contents of protein significantly. The mean protein content was found maximum at $60 \mathrm{~kg} \mathrm{~S} \mathrm{ha}^{-1}$ and thereafter declined linearly upto $120 \mathrm{~kg} \mathrm{~S}$ $\mathrm{ha}^{-1}$ level. The increase in protein content might be due to increase in $\mathrm{N}$-content of mustard which ultimately increased aminoacid and protein content of mustard.
The result confirms the findings of Singh $e t$ al., (1991) and Singh et al., (1998). Application of $60 \mathrm{~kg} \mathrm{~S} h a^{-1}$ gave significantly higher seed yield, economics, oil yield, protein yield and nutrients uptake $\left(\mathrm{kg} \mathrm{ha}^{-1}\right)$ than control, 20 and $40 \mathrm{~kg} \mathrm{~S}^{-1}$ during experimental years (Verma et al., 2012). Both the organic manures were equally effective in reducing the protein content in seed which might be due to reduction in $\mathrm{N}$ content as a result of immobilization of soil $\mathrm{N}$ by microbes activated by organic manure during their decomposition. The interaction effect was also significant which indicated that inorganic $\mathrm{S}$ application upto $60 \mathrm{~kg} \mathrm{~S} \mathrm{ha}^{-1}$ level was most suitable for increasing protein content in seed. In conclusion, the maximum total $\mathrm{N}, \mathrm{P}$ and $\mathrm{K}$ uptake showed the synergistic behaviour at 
lower level of S-application with N, P and K content in seed and stover and antagonistic at higher level of S-application. The beneficial effect of organic manure was also apparent in increasing total $\mathrm{N}, \mathrm{P}$ and $\mathrm{K}$ uptake. Biogas slurry (BGS) proved better as compared to FYM in increasing total N, P and K uptake by mustard. The N: $S$ ratio in mustard seed and stover was found highest at $60 \mathrm{~kg} \mathrm{~S} \mathrm{ha}^{-1}$, and the lowest N: S ratio was observed at highest level of $\mathrm{S}$ application $\left(120 \mathrm{~kg} \mathrm{ha}^{-1}\right)$ in both seed and stover. Sulphur application enhanced the protein content significantly in mustard seed.

\section{References}

Ali, M. 1991. Consolidated report on kharif pulses (1990-91). DPR, Kanpur.

Aulakh, M.S., Pasricha, N.S. and Azad, A.S. $1990 . \quad$ Phosphorus-sulphur interrelationships for soybeans on $\mathrm{P}$ and $\mathrm{S}$ deficient soil. Soil Sci 150: 705709.

Biswas, D.R., Ali, S.A. and Khera, M.S. 1995. Response of Gobhi Sarson (Brassica naphus L., ISN-706) to nitrogen and sulphur. J. Indian Soc. Soil Sci. 43: 220-223.

Chaubey, AK. and Dwivedi, K.N. 1995. Effect of N, P and $S$ and their interactions on yield and nutrient uptake by linseed (Linum usitatissimum). J. Indian Soc. Soil Sci. 43: 72-75.

Chesmine L and Yien C.H. 1951. Turbidimetric determination of available sulphates. Soil Science Society of America Proceedings. 15: 149-151.

Das, K.N. and Das, K. 1994. Effect of sulphur and nitrogen fertilization on yield and $\mathrm{N}$ uptake by rapeseed. J. Indian Soc. Soil Sci. 42. 476-478.

Das SK, Biswas B, Jana K.2016. Effect of farm yard manure, phosphorus and sulphur on yield parameters, yield, nodulation, nutrient uptake and quality of chickpea (Cicer arietinum L.). J Appl. \& Nat. Sci. 8(2): 545549.

Dwivedi, K.N., Chandra, P. and Pandey, U.C. 1996. Relative efficacy of sulphur carriers on yield of and nutrients uptake by blackgram. J. Indian Soc. Soil Sci. 44: 790-791.

Food energy- methods of analysis and conversion factors FAO food and nutrition paper 77. Report of a technical workshop, Rome 3-6 December, 2002.

Hazra, C.R. 1988. Sulphur fertilization of forages for yield and quality. Proc. TSI-FAI Symp. Sulphur in Indian Agriculture, New Delhi, SIV4/1-13.

Jackson, M.L. 1978. Soil Chemical Analysis. Prentice Hall of India, New Delhi.

Jaggi, R.C., Kanwal, R.S. and Dixit, S.P. 1995. Effect of fertilizer $\mathrm{N}$ and $\mathrm{S}$ interaction on composition and uptake of nutrients by linseed on acid Alfisol. J. Indian Soc. Soil Sci. 43: 611-615.

Kachhave, K.G., Gawande, S.D., Kohire, O.D. and Mane, S.S. 1997. Influence of various sources and levels of sulphur on nodulation, yield of and uptake of nutrients by chickpea. J. Indian Soc. Soil Sci. 45: 590-591.

Lindsay, W.L. and Norvell, W.A 1978. Development of a DTPA soil test for zinc, iron, manganese and copper. Soil Sci. Soc. Am. Proc. 42: 421-428.

Najar G.R., Singh SR, Akthar F, Hakeem S.A. 2011. Influence of sulphur levels on yield, uptake and quality of soyabean (Glycine max) under temperate conditions of Kashmir valley. Indian J Agric. Sci., 81(4): 340343.

Pasricha, N.S., Aulakh, M.S., Bahl, G.S. and Baddesha, H.S. 1987. Nutritional requirements of oilseeds and pulse crops in Punjab (1975-89). Res. Bull. 
No. 15, P.AU., Ludhiana, pp. 92.

Patel, P.C. and Patel, J.R. 1994. Effect of phosphorus and sulphur on forage yield and nutrient uptake by lucern. J. Indian Soc. Soil Sci. 42: 154-156.

Piper, C.S. 1966. Soil and Plant Analysis. Inter Science Publ., New York.

Randhawa, N.S. 1995. National Seminar on Development in Soil Sci., Indian Soc. Soil Sci., Nov. 2-5, pp. 167.

Rauth, M.S. and Ali, M. 1985. Studies on P and $S$ nutrition on mustard under rainfed conditions. Proc. TNAU-FACT Seminar on Sulphur, Coimbatore, 143148.

Sachdev, M.S. and Deb, D.L. 1990. N and S uptake and efficiency in mustard moong-maize cropping system. Fertil. News 35 (7): 49-55.

Sarkunan, V., Mishra, A.K. and Mohapatra, A.R. 1998. Effect of phosphorus and sulphur on yield and uptake of $\mathrm{P}$ and $\mathrm{S}$ by rice. J. Indian Soc. Soil Sci. 46 476477.

Sharma, D N., Khaddar, V.K., Sharma, R.A. and Singh, D. 1991. Effect of different doses and sources of sulphur on the quality and yield of mustard. J. Indian Soc. Soil Sci. 39: 197-200.

Singh, D. and Chhiba, I.M. 1991. Evaluation of some sources of sulphur using maize and wheat as test crops. J. Indian Soc. Soil Sci. 39: 514-516.

Singh, K.K., Kumar, R. and Pingolia, A.L. 1998. Effect of sources and levels of sulphur on oil and protein content of mustard. J. Indian Soc. Soil Sci. 46: 150-151.

Sinha, R.B., Sakal, R. and Kumar, S. 1995. Sulphur and phosphorus nutrition of winter maize in calcareous soil. $\mathrm{J}$. Indian Soc. Soil Sci. 43: 413-418.

Tabatabai, M.A 1982. Sulphur. In Methods of Soil Analysis. Part 2. Chemical and Microbiological Properties. Agronomy Monograph No. 9 (C.A Black, Ed.), 2nd ed. pp. 501-538. Soil Science Society of America, Madison. (c.f. Soil Biol. Biochem. (1994). 26: 1507-1514.

Verma CK, Prasad K, Yadav DD.2012. Studies on response of sulphur, zinc and boron levels on yield, economics and nutrients uptake of mustard [Brassica juncea (L.) Czern \& Coss]. Crop Res. 44(1 \& 2):75-78.

Walkley A and Black CA. 1934.An examination for wet acid method for determination soil organic matter and proposed modification of the chromic acid titration method. Soil Science. 37: 29-38.

\section{How to cite this article:}

Anand Prasad Rakesh and Vandana Kumari. 2020. Studies on Effect of Different Levels of Sulphur Application with Combined Use of Organic Manures on Nutrients Uptake, NutrientsRelationships and Protein Content in Indian Mustard. Int.J.Curr.Microbiol.App.Sci. 9(04): 2718-2733. doi: https://doi.org/10.20546/ijcmas.2020.904.322 